\title{
Bacterial Protein Characterization of Streptococcus agalactiae by SDS-page Method for Subclinical Mastitis Irradiated Vaccine Materials in Dairy Cattle
}

\author{
B.J. Tuasikal ${ }^{1^{*}}$, I.W.T. Wibawan ${ }^{2}$, F.H. Pasaribu ${ }^{2}$ and S. Estuningsih ${ }^{2}$ \\ ${ }^{I}$ Center for the Application of Isotopes and Radiation Technology, National Nuclear Energy Agency \\ Jl. Lebak Bulus Raya, Kotak Pos 7002, Jakarta 12070, Indonesia \\ ${ }^{2}$ Faculty of Veterinary Medicine, Bogor Agriculture Institute, Bogor, Indonesia
}

ARTICLE INFO

Article history:

Received 04 May 2012

Received in Revised form 27 November 2012

Accepted 27 August 2012

Keywords:

Protein characterization

Streptococcus agalactiae

Mastitis irradiated vaccine

\begin{abstract}
A B S T R A C T
A study have been conducted to isolate and characterize bacterial protein $\mathrm{S}$. agalactiae, which is antigenic and can be used to test immunogenicity of vaccine in order to manufacture irradiated mastitis (inflammation of the udder) vaccine in ruminant. The study aims to determine the Molecular Weight (MW) bacterial protein S. agalactiae irradiation, which can be used to test the nature of its antigenic caharacteristic. The character of $S$. agalactiae antigenic stimulates antibody induction of the immune system, in which case is the body's defense system against mastitis disease in cattle. In this study, irradiation of gamma ray is used to attenuate the pathogenicity of bacteria by reducing $S$. agalactiae antigenic caharacteristic. Previous research, in irradiation dose orientation before antigenic protein isolation of S. agalactiae, indicated that irradiation lethal dose to $50 \%\left(\mathrm{LD}_{50}\right)$ is $17 \mathrm{~Gy}$. The characterization of S. agalactiae bacteria isolate using SDS-page method results in no significance different between irradiated and non-irradiated group, which indicated by MW range $75-100 \mathrm{kDa}$ base on marker standard which used, or $99 \mathrm{kDa}$ by the linier equation of $\mathrm{Y}=11,60-0.05 \mathrm{X}$ (where $\mathrm{Y}=$ bands distance; $\mathrm{X}=\mathrm{MW}$ standard protein); $\mathrm{r}^{2}=0.99$. In conclusion, 17 Gy irradiation dose does not impair antigenic property of $S$. agalactiae and therefore, can be applied to produce base material of irradiated vaccine for mastitis.
\end{abstract}

(C) 2012 Atom Indonesia. All rights reserved

\section{INTRODUCTION}

Mastitis is a disease with inflammation symptoms at the udder. Mastitis declines milk production yield, and thus become problem for dairy farmers Indonesia whose are generally only keeping 3-4 cows per farmer. According MORRIS [1] mastitis in one udder of the dairy cattle may reduce by $30 \%$ of the overall udder, and therefore reduce the overall milk yield by $10-15 \%$. Overall milk production is found to be reduced by $20 \%$ due to the incidence of mastitis in dairy farm in Garut [2]. Furthermore, according to the BLOOD and RADOSTITS [3] and EUSTICE [4], the economic losses from the decline of farm milk productivity due to mastitis, could reach $70 \%$.

In this experiment, Streptococcus agalactiae bactery is used due to its predominant bacterial cause of mastitis found in Cisurupan districts of Garut dairy farm [5]. Most of the mastitis was

\footnotetext{
Corresponding author.

E-mail address: b_jeanne@batan.go.id
}

treated by antibiotics application, which is primarily eliminates bacteria. However, the uncontrolled use of antibiotics in the field may leads to new problems of the resistant germs-caused mastitis to antibiotics and drugs residue in milk [6]. In this situation, difficulty is found in bacteria caused mastitis eradication, and antibiotic residues in milk may appear and can be harmful to human health.

The incidence of antibiotics resistance and drugs residues lead to find other alternative way to anticipate mastitis cases found in many dairy farms as additional in managing farms by application of mastitis vaccine. Utilization of gamma radiation in weaken the pathological bacteria caused mastitis of Strepcococcus agalatiae will be discuss in this study. The attenuation of S. agalactiae using gamma radiation will be expected to weaken pathogenicity property of bacteria but remain potential in stimulate immune response of the animal.

The origin of antigenic property of $S$. agalactiae has been known to be its protein 
membrane, which can induce the formation of antibodies as the immune response system of cattle. It is deemed necessary that isolation and characterization of bacterial membrane proteins to examine the antigenic properties of S. agalactiae.

\section{EXPERIMENTAL METHODS}

\section{Membrane's protein concentration determination}

\section{Materials and equipments}

Streptococcus agalactiae bacterial sample, which were cultured in Brain Heart Infusion media (BHI) Broth, physiological saline, a solution of reagent coomassie Blue, and Bovine Serum Albumen (BSA) were used as based material while test tubes, sonicator, centrifuges, and UV-VIS spectrophotometer contributed as equipment used in this experiment.

\section{Bacterial cell preparation}

Samples of bacteria, which have been grown and maintained in BHI Broth and were subjected to irradiation with doses of $0 \mathrm{~Gy}$ and $17 \mathrm{~Gy}$, were centrifuged at $10,000 \mathrm{~g}$ for 10 minutes. Bacterial cell pellet was removed and then washed using physiological saline, followed with diluted in physiological saline to $1.5 \mathrm{ml} / \mathrm{v}$. Cell suspension in a tube is inserted into sonicator, which previously had sonicator tube rinsed with physiological saline (Fig. 1a and 1b) for 3 minutes at level 4.

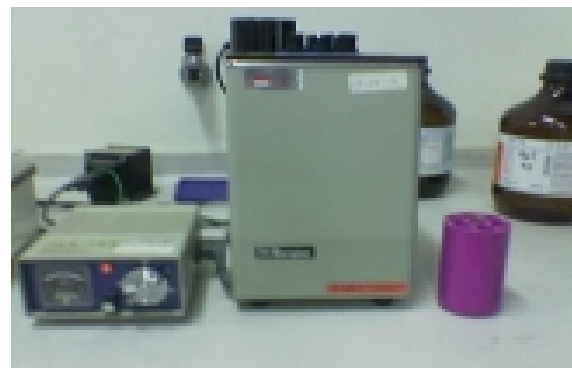

(a)

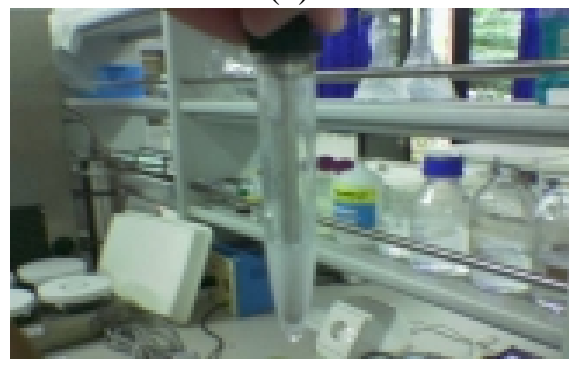

(b)

Fig. 1. (a) Sonicator tube, (b) Sonicator equipment.
Result of this sonication then was then removed using eppendorf into a new tube, and then centrifuges at $11.000 \mathrm{~g}$ for 3 minutes. Supernatant obtained was taken and stored at $0-4{ }^{\circ} \mathrm{C}$ for protein concentration determination.

\section{Coomassie Blue reagent solution preparation}

A total of $100 \mathrm{mg}$ of Coomassie brilliant Blue G-250 dissolved in $50 \mathrm{ml}$ of ethanol $95 \%$. An amount of $100 \mathrm{ml}$ phosphoric acid 85\% (w/v) was then added and diluted with distilled water to reach 1 liter. The solution was filtered with filter paper. Final concentration of each reagent is $0.01 \%$ (w/v) Coomassie brilliant Blue G-250, 4.7\% (w/v) ethanol, $8.5 \%(\mathrm{w} / \mathrm{v})$ phosphoric acid. This solution is stable for a period of several months, depending on storage conditions.

\section{Standard solution preparation}

Standard solutions should be made fresh and this would keep stable for the period of only one week if kept refrigerated. In preparing Bovine Serum Albumin standard (BSA), a weighed of $10 \mathrm{mg}$ BSA was added to $10 \mathrm{ml}$ in distilled water. The solution was allowed to dissolve by itself to prevent foaming by the protein. A series of standard was then made following the concentration protocol as shown in the Table 1 and Fig. 2a.

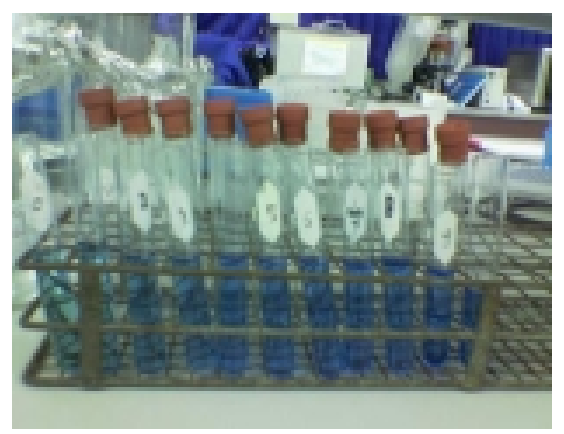

(a)

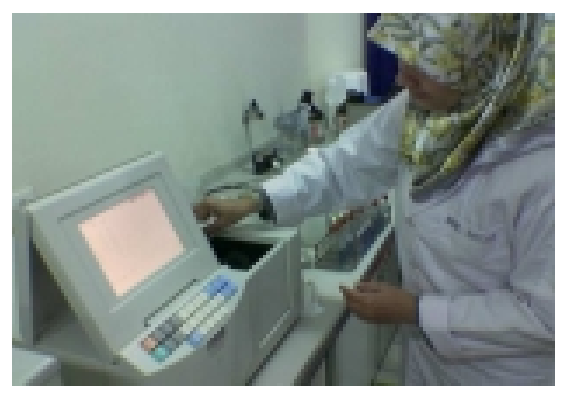

(b)

Fig. 2. (a) Standard solution, (b). Protein concentration determination in spectrophotometer. 
Table 1. Establishment of protein standard solution using BSA (Bovine Serum Albumin)

\begin{tabular}{ccc}
\hline No. of tubes & $\begin{array}{c}\text { Volume protein } \\
(\text { BSA })(\mathrm{ml})\end{array}$ & $\begin{array}{c}\text { Volume aquades } \\
(\mathrm{ml})\end{array}$ \\
\hline 1 & 0 & 10 \\
2 & 0.1 & 0.9 \\
3 & 0.2 & 0.8 \\
4 & 0.3 & 0.7 \\
5 & 0.4 & 0.6 \\
6 & 0.5 & 0.5 \\
7 & 0.6 & 0.4 \\
8 & 0.7 & 0.3 \\
9 & 0.8 & 0.2 \\
10 & 0.9 & 0.1 \\
11 & 1.0 & 0 \\
\hline
\end{tabular}

Each of solution (Table 1) was pipetted of $0.1 \mathrm{ml}$ into a new clean tube and this also imposed to the sample where protein should be determined.

A total of $5 \mathrm{ml}$ of Coomassie Blue reagent was pipetted into each test tube, which was filled with solution of protein (BSA) or samples, then mix using vortex. After 2 minutes, absorbance of the solution was measured at $595 \mathrm{~nm}$, and all absorbance reading was arranged within one-hour. Standard curve and protein concentration in the sample is directly read using spectrophotometer (Fig. 2b).

\section{Protein analysis using Sodium Decodyl Sulphate Polyacrylamide Gel Electrophoresis (SDS-PAGE) technique}

\section{Materials and equipments}

Irradiated S. agalactiae at the level dose of 0 Gy and 17 Gy as samples, was used in this experiment. The experiment was also involving acrylamide bis $(30 \% \mathrm{~T}, 2.67 \% \mathrm{C}), 1.5 \mathrm{M}$ Tris $\mathrm{HCl} \mathrm{pH}$ $8.8,10 \%(\mathrm{w} / \mathrm{v})$ sodium dodecyl sulphate (SDS), $10 \%(\mathrm{w} / \mathrm{v})$ ammonium persulphate, buffer samples, $5 \mathrm{x}$ running buffer $(1 \mathrm{x}=25 \mathrm{mM}$ Tris, $192 \mathrm{mM}$ glycin, 0.1\% SDS pH 8.3), Coomasie Blue solution, buffer solution, Protein ladder (protein marker with MW between $25-225 \mathrm{kDa}$ ) and electrophoresis equipment.

\section{Gel preparation}

Electrophoresis gel were made in two steps. The first step was preparing separating gel, which then followed with second step in preparing stacking gel at 1 hour after the separating gel polimerated as shown in Fig. 3. The gel composition is shown in Table 2.
Table 2. Composition of separating and stacking gel.

\begin{tabular}{lcc}
\hline & Separating gel & Stacking gel \\
\multicolumn{1}{c}{ Materials substance } & (375 M Tris pH & $(125 \mathrm{M}$ Tris pH \\
& $8.8)$ & $6.8)$ \\
& $(12 \%)$ & $(4 \%)$ \\
\hline Acrylamid Bis $(30 \% \mathrm{~T}, 2.67 \% \mathrm{C})$ & $2.4 \mathrm{ml}$ & $260 \mu \mathrm{l}$ \\
$1.5 \mathrm{M}$ Tris-HCl pH 8.8 & $1.5 \mathrm{ml}$ & - \\
$0.5 \mathrm{M}$ Tris-HCl pH 6.8 & - & $0.5 \mathrm{ml}$ \\
$10 \%(w / v)$ SDS & $60 \mu \mathrm{l}$ & $20 \mu 1$ \\
$10 \%($ w/v) ammonium persulphate & $30 \mu \mathrm{l}$ & $10 \mu 1$ \\
$\mathrm{H}_{2} \mathrm{O} /$ Aquabides & $2 \mathrm{ml}$ & $1.22 \mathrm{ml}$ \\
Temed & $3 \mu \mathrm{l}$ & $2 \mu \mathrm{l}$ \\
\hline
\end{tabular}

Following gel solution poured into chamber glass, sterile water was added at the top of the gel in order to make a flat surface of the gel and let for 60 minutes for gel to polymerize. Excess water found at the top is removed and then stacking gel is added. Immediately after that, glass comb is placed to make wells in the gel and let the gel clotted for approximately 60 minutes. For some reasons, the work might be postponed by storing the gel at room temperature covered with wet plastic cover. Separation gel and gel volume collector can be enlarged or reduced according to the available size of the gel mold. In this lab used electrophoresis equipment SIGMA.

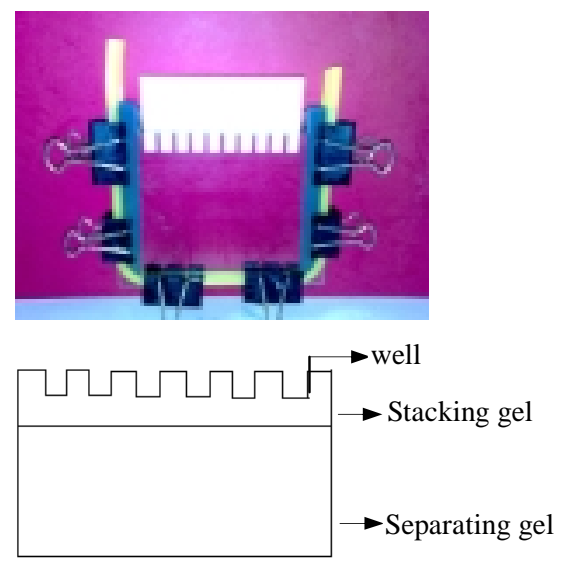

Fig. 3. Gel preparation for protein analysis.

\section{Sample preparation}

An amount of $10 \mathrm{ml}$ sample was taken and placed in ependorf tube, then added $10 \mathrm{ml}$ sample buffer. The solution was then heated at $60^{\circ} \mathrm{C}$ for 5 minutes to get mix for denaturation (Fig. 4), and then stored in ice before use.

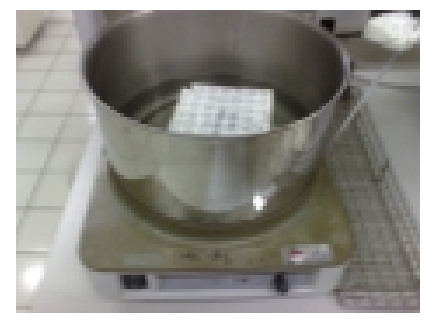

Fig. 4. Protein denaturation at $60^{\circ} \mathrm{C}$ for 5 minutes. 


\section{Electrophoresis}

Comb was removed after the printed gel formed, and then submerged with electrophoresis buffer (tris-glysine) in the electrophoresis tank. Chambers were cleaned by filling $10 \mathrm{ml}$ of mixture solution of sample and buffer to each chamber to clean the remaining gel. Protein marker was also added to each of chamber. Electrophoresis tank chambers then closed, and connected to a $50 \mathrm{~mA}$ (100 volts) power supply for 3 hours or until the lower gel raised to approximately $1 \mathrm{~cm}$ above the lower limit of gel. The overall electrophoresis process is performed at $4^{\circ} \mathrm{C}$ (Fig. 5).

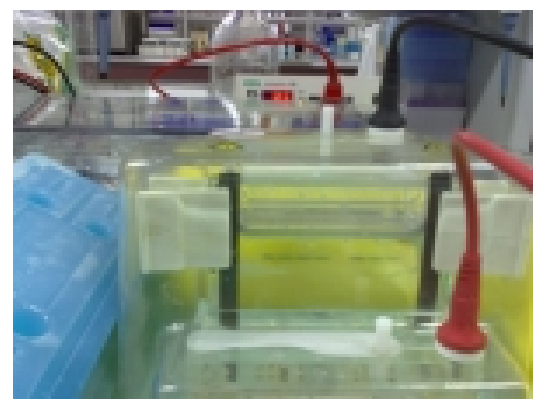

Fig. 5. SDS-PAGE technique for protein analysis.

\section{Gel coloring or Coomassie Blue staining}

After electrophoresis completed, gel was removed from the tank chamber and from the moulding glass. The excess of stacking section was disposed with cutter, while the separating section is colored with coomassie blue. Gel then shaken for about 30 minutes until protein bands appear on a blue gel (Fig. 6).
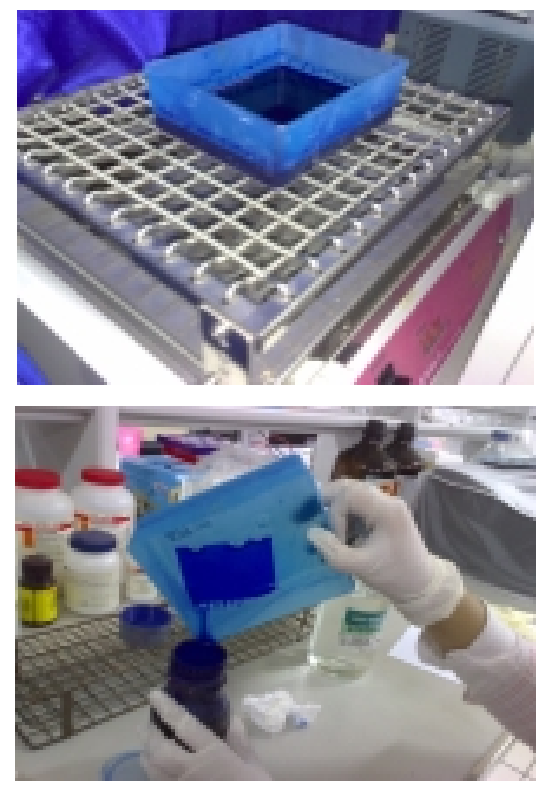

Fig. 6. Gel coloring using Coomassie blue.
The excess of coomassie blue was removed from the gel sheet and then washed with buffer until gel become clear and only the protein bands are visible. This gel sheet can be preserved in a sealed plastic.

\section{RESULTS AND DISCUSSION \\ Protein concentration determination}

Spectrophotometer result in protein concentration determination is shown in the Table 3.

Table 3. Protein concentration determination in standar solution and irradiated S. agalactiae sample suspension in 4 treatments.

\begin{tabular}{lcc}
\hline Sample code & Absorbans & $\begin{array}{c}\text { Protein concentration } \\
(\mathrm{mg} / \mathrm{ml})\end{array}$ \\
\hline $\mathrm{I}_{0}(0 \mathrm{~Gy})$ & 0.269 & 0.750 \\
$\mathrm{I}_{17}(17 \mathrm{~Gy})$ & 0.130 & 0.521 \\
$\mathrm{II}_{0}(0 \mathrm{~Gy})$ & 0.049 & 0.385 \\
$\mathrm{II}_{17}(17 \mathrm{~Gy})$ & 0.022 & 0.262 \\
\hline
\end{tabular}

Gamma ray irradiation leads to lowering bacteria cell population. Ionizing radiation or gamma ray of high energy electron can cause direct biological effects on microbes, especially to prime molecules such as deoxyribonucleic acid or DNA. Therefore, the effect of radiation on $\mathrm{S}$. agalactiae require further study, particularly in the possibility of chromosomal DNA damage [7].

The absorbance values in Table 3 shows that protein concentration is proportionally to the absorbance reading. The higher protein concentration, the higher absorbance is read from the spectrophotometer [8].

\section{SDS-PAGE for protein analysis}

Result of protein analysis using SDS-PAGE technique on extracted bacteria sample of protein S. agalactiae cell is shown in the Fig. 7.

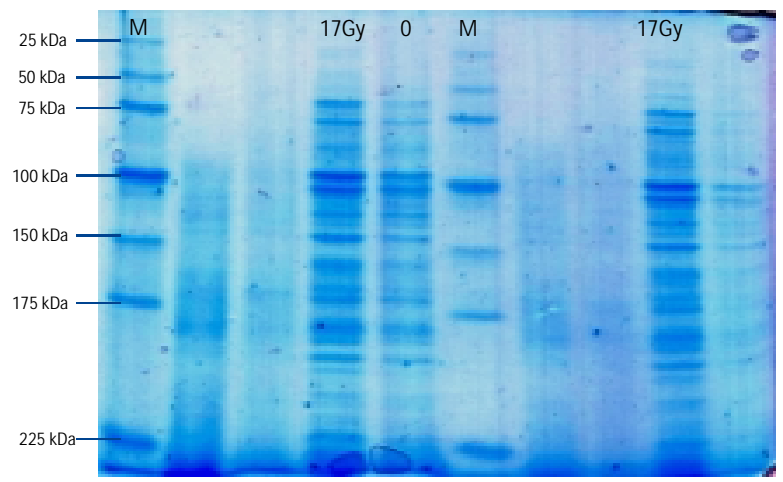

Fig. 7. S. agalactiase protein ribbon pattern in polyacrilamide $12 \%$ gel. Ribbon line 4 with $17 \mathrm{~Gy}$ and ribbon line 5 with 0Gy irradiation dose, $\mathrm{M}=$ marker protein molecular weight: $25-225 \mathrm{kDa}$. 
Two samples of bacteria (treated with 0 and 17 Gy irradiation dose) show the visibility of protein band is formed without difference protein ribbon patterns, which indicated that irradiation of $17 \mathrm{~Gy}$ to $S$. agalactiae does not alter antigenic properties of the bacteria.

Characterization of protein properties, using SDS-Page of S. agalactiae caused mastitis bacteria, between non-irradiated and 17 Gy irradiated treatment groups shows no significance difference as it is indicated by the molecular weight of both groups are in the range of $75-100 \mathrm{kDa}$ base on marker standard which used, or $99 \mathrm{kDa}$ by the linier equation of $\mathrm{Y}=11,60-0.05 \mathrm{X}$ ( $\mathrm{Y}=$ distance bands; $\mathrm{X}=\mathrm{MW}$ standard protein ); $\mathrm{R}^{2}=0.99$. The result of this experiment also indicate that $\mathrm{S}$. agalactiae is inactivated, by 17 Gy irradiation dose, but remain antigenic due to its protein MW more than 10,000 Da. It had been shown that minimum requirement for antigen to stimulate the development of antibody on the immune system have the minimum of MW of 10,000 Da [9]. Due to antigenic potential of irradiated S. agalactiae, utilizing radiation to attenuate $S$. agalactiae to form base material for vaccine is possible. Therefore, from the experiment, exposing S. agalactiae with 17 Gy of gamma ray radiation can be use to develop base material of irradiation vaccine againts mastitis.

Protein electrophoresis used in this experiment is basically had the same principles as it is used in DNA electrophoresis. However, in protein electrophoresis, an addition of sodium dodecyl sulphate polycrilamide (SDS) was applied, which then implied to protein dissociation to its subunit protein, and hence it is called SDS-page technique. Unlike in DNA, protein analysis in protein-electrophoresis was done by staining color coomassie blue, where this compound is added together with the sample. Protein staining can also be done by employing silver nitrate, which is more sensitive as compare to coomassie blue.

Organism' proteins can be separated based on their MW. Proteins with higher MW will move faster than the protein having a lower MW. Polyacrilamide gel, has the characteristic to filter protein with small MW, therefore, protein with a bigger MW will be at the lowest position, while the smaller MW at the top. Employing polyacrylamide in the protein determination confirming the separation of MW-based protein in this experiment.

\section{CONCLUSION}

Protein characterization from $S$. agalactiae isolates using SDS-Page technique on non-irradiated (0 Gy) and irradiated (17 Gy) treatment group, shows no difference in the antigenic properties of the bacterial as indicated by molecular weight (MW). The bacterial protein $\mathrm{MW}$ of the two groups are ranged between $75-100 \mathrm{kDa}$ or $99 \mathrm{kDa}$. Irradiation dose of $17 \mathrm{~Gy}$ does not alter the antigenic properties of $S$. agalactiae and that therefore radiation technique can be used to produce base-material for mastitis irradiated vaccine.

\section{REFERENCE}

1. R.S. Morris, Aust. Vet. J. 49 (1973) 153.

2. T. Tjiptosumirat, Nuclear Technique Application for The Improvement of Large Ruminant Reproduction Performance, Center for the Application of Isotopes and Radiation Technology (CAIRT), NAEA (2010) 21. (in Indonesian).

3. D.C. Blood and O.M. Radostits, Mastitis, Veterinary Medicine, $7^{\text {th }}$ Ed. Bailliere, Thindall, Philadelphia (1989) 537.

4. R.F. Eustice, Factors Affecting Mastitis Susceptibility, Guide for Dairy Cow Management, Nandi Amerta Agung, Salatiga, (1988) 171. (in Indonesian).

5. T. Tjiptosumirat, A.P. Murni and B.J. Tuasikal, Application of Radioimmunoassay (RIA) Technique for Reproductive Efficiency Improvement and Mastitis Bacterial Identification in Ruminant, Research and Development Technical Report, CAIRT, NAEA, Jakarta (2005). (in Indonesian).

6. S. Chotiah, Animal Disease XXV 45 (1993) 15.

7. B.J. Tuasikal, I. Sugoro, T. Tjiptosumirat and M. Lina, Science and Nuclear Technology 4 (2003) 137. (in Indonesian).

8. S. Khodijah, B.J. Tuasikal and Yusneti, Growth of Streptococcus agalactiae as Causative Bacteria of Subclinical Mastitis in Dairy Cattle, Proc. National Seminar for Livestock and Veterinary, Bogor (2006) 233. (in Indonesian).

9. G. Lindahl, et al., Surface Protein of Streptococcus agalactiae and Related Proteins in Other Bacterial Pathogens, Clinical Microbiological Reviews (2006) 102. 